\title{
Epidemiological, Clinical and Etiological Aspects of Ascites in the Medicine Department at the Departmental University Hospital of Borgou
}

\author{
A. C. Dovonou', A. C. Alassani ${ }^{*}$, K. Saké1, S. Adè1, C. A. Attinsounon1, S. Ahoui1, J. Degla1, \\ Tognon F. Tchégnonsi ${ }^{1}$, D. M. Zannou ${ }^{2}$, G. Adè2, F. Houngbé ${ }^{2}$ \\ ${ }^{1}$ Departemental Teaching Hospital of Borgou, Parakou, Benin \\ ${ }^{2}$ National Teaching Hospital, Cotonou, Benin \\ Email: *adebayoalassani@gmail.com
}

How to cite this paper: Dovonou, A.C., Alassani, A.C., Saké, K., Adè, S., Attinsounon, C.A., Ahoui, S., Degla, J., Tchégnonsi, T.F., Zannou, D.M., Adè, G. and Houngbé, F. (2017) Epidemiological, Clinical and Etiological Aspects of Ascites in the Medicine Department at the Departmental University Hospital of Borgou. Open Journal of Internal Medicine, 7, 58-63.

https://doi.org/10.4236/ojim.2017.73006

Received: June 6, 2017

Accepted: August 8, 2017

Published: August 11, 2017

Copyright $\odot 2017$ by authors and Scientific Research Publishing Inc. This work is licensed under the Creative Commons Attribution International License (CC BY 4.0).

http://creativecommons.org/licenses/by/4.0/

\begin{abstract}
Goals: The study has been initiated in order to describe the epidemiological, clinical and etiological aspect of the ascites. Patients and methods: This was a retrospective and descriptive study on the patients with an ascite and followed at the medicine department of Borgou departmental teaching hospital. Results: A total of 190 patients have presented an ascite or a hospital prevalence at $3.93 \%$. A male predominance has been observed with a sex-ratio at 1.7. The average age was $39.7 \pm 13.9$ years. The reason for consultation is dominated by the increase of the abdominal volume (69.5\%). The ascite fluid is macroscopically yellow citrine. The cirrhosis $(28.5 \%)$ and the heart diseases $(18.6 \%)$ were the most encountered causes of the ascites. Conclusion: The etiologies of ascites are various and dominated by the hepatic cirrhosis and the heart diseases.
\end{abstract}

\section{Keywords}

Profile, Ascite, Medicine Department, Parakou

\section{Introduction}

The ascite which is the effusion of fluid in the peritoneal cavity is a sign frequently encountered in the medical practice and is related to various causes [1]. It stems from many mechanisms notably portal hypertension, the peritoneum inflammatory, the increase of the hydrostatic pression and the decrease of the oncotic pression [2] [3]. It brings a diagnostic and therapeutic problem [4]. The 
diagnosis involves clinic but also some paraclinical examinations, sometimes none available in underdeveloped countries. When the diagnosis has been made, the treatment is sometime not available or even inefficient due to the severity of the pathology. The etiologies are multiple and dominated by the hepatomegalies observed in $85 \%$ of the cases [5]. The others etiologies are related to heart diseases, to kidney pathologies or to the peritoneal tuberculosis [6] [7]. The prognosis is variable and depends on the incriminated pathology; it is serious when it's the hepatopathies with a mortality which can exceed 50\% [8] within the next two years but may have a favourable prognosis for the others causes notably cardiac or renal ones when the diagnosis and the treatment are early. So, the pathologies responsible of an ascite knowledge is important in order to take preventive measures. In Benin notably in the north, the extent of the ascite as well as its different causes is unknown. This study has been initiated to describe the epidemiological, clinical and etiological aspect of the ascites.

\section{Patients and Method}

This was a retrospective and descriptive study covering the period between the $1^{\text {st }}$ January 2010 and $31^{\text {st }}$ December 2014 . The study population was made of all the patients who have consulted or have been hospitalized in Departemental Teaching Hospital of Borgou during the study period. No patients were excluded. The retrospective nature of the study did not require patient consent. The ascite has been highlighted by clinical examination in case of average or massive fluid or by the abdominal ultrasound scan in case of smaller fluid. The etiological research has been made with the support of a clinical examination, the examination of the ascites fluid, the abdominal and pelvic ultrasound and others complementary examinations according to the cases. The clinical examination looked for hepatocellular deficiency signs (palmar erythrosis, spider nevi and clumping of the fingers), a hepatomegaly as well as its characters (bottom edge, surface, consistency, and sensitivity), the jugular turgidity, hepatojugular reflux, a splenomegaly, the venous collateral circulations, the presence of adenopathies. The ascites fluid examination has appreciated the macroscopic aspect, the proteins count, the cytology with the differential leukocyte count, the bacteriology of the fluid and the research of abnormal cells in the fluid. The pelvic and abdominal ultrasound scan has assessed the liver characters (size, echopattern, presence of nodule), the portal vein aspect (dilation or thrombosis) and the aspect of the sus hepatic vein, presence of splenomegaly, kidney and pelvic organs aspect. The rest of the check-up was about the prothrombin, the transaminases level, the serum calcium level, the complete blood count, the serum creatinine level, the alpha-fetoprotein, the serum albumin level, the serum protein level and the 24-hours urine protein test. The analysis is made with the software Epi Data, version 3.1.

\section{Results}

Out of the total of 4826 patients admitted in the medicine department during the 
study period, 190 have presented an ascite or a hospital prevalence at 3.93\%. Among the patients having an ascite, a male predominance has been observed with a sex-ratio at 1.7. The average age was $39.7 \pm 13.9$ years old with the extremes 16 and 74 years; 4 patients of 10 (41.6\%) were between 30 and 44 years. The reason for consultation of the patients having an ascite is dominated by the abdominal volume increase (69.5\%) followed by odema of the lower limbs (31.1\%) (Table 1).

On the macroscopic level, the ascite fluid is in the majority yellow citrine (78.9\%). The ascite causes were dominated by the cirrhosis (28.5\%) followed by the heart diseases (18.6\%) (Table 2).

\section{Discussion}

This study has as goal to describe the ascites etiologies at the medicine department. This was a retrospective study with data collected from the patients medical records. This methodology presents insufficiencies but the proper recordkeeping in the department minimizes bias. The etiological research of the ascite cause that necessitate a body of clinical and paraclinical arguments is not an easy task because of the patients lack of means but also the lack of the necessary technical facilities for the realization of some complementary examination.

The ascite is a non-rare sign in the medicine department with a hospital prevalence at $3.93 \%$. This prevalence is lower than the one at $11.4 \%$ reported by

Table 1. Patients with an ascite distribution by the sex, the age and the reason for consultation $(\mathrm{n}=190)$.

\begin{tabular}{|c|c|c|}
\hline Variables & $\mathbf{N}$ & $\%$ \\
\hline \multicolumn{3}{|l|}{ Sex } \\
\hline Female & 71 & 37.4 \\
\hline Male & 119 & $62.6 \%$ \\
\hline \multicolumn{3}{|l|}{ Age (years) } \\
\hline $15-29$ & 47 & 25 \\
\hline $30-44$ & 79 & 41.6 \\
\hline $45-59$ & 42 & 22 \\
\hline 60 and more & 22 & 11.4 \\
\hline \multicolumn{3}{|l|}{ Reason for consultation } \\
\hline Increase of the abdominal volume & 132 & 69.5 \\
\hline Abdominal pain & 19 & 10 \\
\hline Dyspnea & 26 & 13.7 \\
\hline Oedema of the lower limbs & 59 & 31.1 \\
\hline Hepatomegaly & 12 & 6.3 \\
\hline Icteria & 9 & 4.7 \\
\hline Others & 34 & 17.9 \\
\hline
\end{tabular}


Table 2. Macroscopic aspect and etiologies of the ascite fluid $(n=190)$.

\begin{tabular}{|c|c|c|}
\hline Variables & $\mathbf{N}$ & $\%$ \\
\hline \multicolumn{3}{|c|}{ Macroscopic aspect of the ascite fluid } \\
\hline Clear & 4 & 2.1 \\
\hline Chylous & 6 & 3.2 \\
\hline Cloudy & 6 & 3.2 \\
\hline Hemorrhagic & 24 & 12.6 \\
\hline Yellow citrine & 150 & 78.9 \\
\hline \multicolumn{3}{|l|}{ Ascites causes } \\
\hline Cirrhosis & 54 & 28.5 \\
\hline Heart diseases & 35 & 18.6 \\
\hline Nephrotic syndrome & 27 & 14 \\
\hline Hepatocellular carcinoma & 25 & 13 \\
\hline Chronic kidney failure & 20 & 10.5 \\
\hline Peritoneal tuberculosis & 20 & 10.5 \\
\hline Peritoneal carcinomatosis & 4 & 2.3 \\
\hline Others & 5 & 2.6 \\
\hline
\end{tabular}

Sawadogo [9] in Burkina Faso for the study he realized at medicine department. The difference in the methodology and the context can justify this difference. The study of Sawadogo was transversal and included all the patients admitted in the department and who had an ascite. This methodology has the advantage to consider all the patients and doesn't deal with the matter of patients' medical records loss or the loss of important information. The retrospective character of this study with the eventual loss of some records cannot relate the true extent of ascite in the department. A further prospective study will allow the assessment of the true ascite extent. When the study is realized in hepato-gastroenterology department, the prevalence is higher and can reach $20 \%$ as Kodjoh et al. [10] reported in their study in Cotonou. The patient population having an ascite is young with the average age $39.7 \pm 13.9$ years. Jaffri [7] and Nakhale [11] have reported similar average ages with respectively $37.83 \pm 10.28$ and $42.41 \pm 7.72$ years. A male predominance has been observed, confirming the results reported by Bindu [4] and Kumar [6]. About the reason for hospitalization, the increase of abdominal volume was reported to be the most frequent. In Nakhale [11] and Adhikari [12] study, the increase of the abdominal volume was reported to be in the majority the reason for consultation. Whereas abdominal pain was the most reported reason for consultation, according to the study of Aslam [13] in Pakistan.

4 out of 5 cases show a yellow citrine fluid after the macroscopic examination of the ascite fluid. According to Ouédraogo [1] study, the ascite fluid was mostly yellow citrine (86.6\%). Many pathologies may have an ascite as sign but the he- 
patic cirrhosis was the cause the most frequent in this study. This confirms the tendency reported by most of the studies on the ascites [14] [15] [16]. The cirrhosis is not only the most frequent pathology but also a serious one because the presence of an ascite means a decompensation with a low life expectancy. In front of an ascite, a hepatic cirrhosis has to be investigated. The main causes of hepatic cirrhosis are viral (viral hepatitis $\mathrm{B}$ most of the time but also the $\mathrm{C}$ one) and alcoholism. The vaccination against viral hepatitis $\mathrm{B}$ and the moderation in the consumption of alcohol are necessary to prevent the hepatic cirrhosis. Outside of the hepatic cirrhosis and the heart diseases, the peritoneal tuberculosis, the nephrotic syndrome and the peritoneal carcinomatosis have been also reported by the authors as ascite causes but with a lower proportion [1] [11] [17].

\section{Conclusion}

Ascite is a frequent sign in the internal medicine department, is macroscopically yellow citrine and often touches young and male adults who consult for the abdominal volume increase. It is the manifestation of diverse pathologies dominated by hepatic cirrhosis and heart diseases.

\section{References}

[1] Ouedraogo, S.M., Sawadogo, A., Kyelem, C.G., Yameogo, T.M., Bambara, M.L. and Ouedraogo, A.S. (2016) Contribution of Paraclinic Tests in the Ascites Diagnosis in Bobo-Dioulasso. Revue Africaine de Médecine Interne, 3, 30-35.

[2] Oey, R.C., van Buuren, H.R. and de Man, R.A. (2016) The Diagnostic Work-Up in Patients with Ascites: Current Guidelines and Future Prospects. The Netherlands Journal of Medicine, 74, 330-335.

[3] Ray, D., Chakrabarti, S., Chakraborty, A., Kundu, D. and Bandyopadhyay, R. (2016) A Clinicopathological Study of Ascites with Special Reference to Malignant Etiology in a Tertiary Care Hospital in Kolkata. International Journal of Medical Research and Review, 4, 1102-1107.

[4] Bindu, C.B. and Nayak, U. (2014) Clinical Study of Ascites with Special Reference to Serum-Ascites Albumin Gradient. International Journal of Medical Science and Public Health, 3, 169-172. https://doi.org/10.5455/ijmsph.2013.151120131

[5] Tasneem, H., Shabhaz, H. and Sherazi, B. (2015) Causes, Management and Complications of Ascites: A Review. International Current Pharmaceutical Journal, 4, 370 377. https://doi.org/10.3329/icpj.v4i3.21936

[6] Kumar, B., Sharma, B., Raina, S., Sharma, N., Gupta, D. and Mardi, K. (2016) Etiology of Ascites in Adults Living in the Hills of Himachal Pradesh, India: A Hospital-Based Study. Chrismed Journal of Health and Research, 3, 41-43. https://doi.org/10.4103/2348-3334.172398

[7] Jaffri, M.S., Shaikh, A., Jaffri, M.H., Khushk, A., Shah, M. and Munir, S. (2009) Diagnostic Sensibility and Specificity of Serum Ascites Albumin Gradient in Patients with Ascites. Journal of Liaquat University of Medical \& Health Sciences, 8, 196200.

[8] Khan, F.Y. (2007) Ascites in the State of Qatar: Aetiology and Diagnostic Value of Ascetic Fluid Analysis. Singapore Medical Journal, 48, 434-439.

[9] Sawadogo, A., Ouedraogo, S.M., Kyelem, C.G., Yameogo, T.M., Bambara, M.L. and 
Ouedraogo, A.S. (2016) Apport Contribution of Paraclinic Tests in the Ascites Diagnosis in Bobo-Dioulasso. Journal of the Clinical Biology Society of Benin, 24, 4651 .

[10] Kodjoh, N., Sehonou, J., Sake, K. and Mouala, C. (2008) Morbidity and Mortality in a Hospital Department of Digestive Pathologies in Cotonou. Medecine d Afrique noire Abbreviation, 55, 554-556.

[11] Nakhale, B.D., Dube, A.H., Bhagat, J.P., Ingole, R. and Patil, M. (2016) Clinical Profile and Comparison of SAAG with Ascites Fluid Total Protein (AFTP) in Cases of Ascites at a Tertiary Referral Hospital in Maharashtra. Medicinal Research Reviews, $4,512-518$.

[12] Adhikari, P., Pathak, U.N., Uprety, D. and Sapkota, S. (2012) Profile of Ascites Patient Admitted in Nepal Medical College Teaching Hospital. Nepal Medical College Journal, 14, 111-113.

[13] Aslam, H., Saleem, S., Alvi, A. and Hasan, S. (2012) Epidemiolgy and Symptomatologie of Exudative and Transudative Type of Ascites in Hospitalized Patients. $\mathrm{Pa}$ kistan Journal of Pharmacology, 29, 1-6.

[14] Sul, V., Namey, R. and Deshpande, N. (2017) Serum Ascitc Gradient and Ascitc Fluid Cholesterol-Newer Approach to Evaluate Ascites. International Journal of Clinical and Diagnostic Research, 5, 1-11.

[15] Angeleri, A., Rocher, A., Caracciolo, B., Pandolfo, M., Palaoro, L. and Perazzi, B. (2016) New Biochemical Parameters in the Differential Diagnosis of Ascitic Fluids. Gastroenterology Research, 9, 17-21. https://doi.org/10.14740/gr700w

[16] Younas, M., Sattar, A., Hashim, R., Ijaz, A., Dilawar, M. and Manzoor, S. (2012) Role of Serum-Ascites Albumin Gradient in the Differential Diagnostic of Ascites. Journal of Ayub Medical College, 24, 97-99.

[17] Mehra, D., Thakur, D., Sultania, S., Chaturvedi, A., Agarwal, G. and Kumar, A. (2016) Etiology of Ascites in Adults Living in Rohilkhand Region, India: A Hospital-Based Study. International Journal of Applied Research, 2, 1-4.

\section{Submit or recommend next manuscript to SCIRP and we will provide best service for you:}

Accepting pre-submission inquiries through Email, Facebook, LinkedIn, Twitter, etc. A wide selection of journals (inclusive of 9 subjects, more than 200 journals)

Providing 24-hour high-quality service

User-friendly online submission system

Fair and swift peer-review system

Efficient typesetting and proofreading procedure

Display of the result of downloads and visits, as well as the number of cited articles

Maximum dissemination of your research work

Submit your manuscript at: http://papersubmission.scirp.org/

Or contact ojim@scirp.org 